Article

\title{
Understanding the Impact of Vertical Canopy Position on Leaf Spectra and Traits in an Evergreen Broadleaved Forest
}

\author{
Fangyuan Yu ${ }^{1}$, Tawanda W. Gara ${ }^{2} \mathbb{D}$, Juyu Lian ${ }^{3,4,5,6}$, Wanhui $\mathrm{Ye}^{3,4,5,6}{ }^{\text {, Jian Shen }}{ }^{7}$, Tiejun Wang ${ }^{8} \mathbb{D}, \mathrm{Zhifeng} \mathrm{Wu}^{1}$ \\ and Junjie Wang ${ }^{9, *(D)}$
}

check for

updates

Citation: Yu, F.; Gara, T.W.; Lian, J.; Ye, W.; Shen, J.; Wang, T.; Wu, Z.;

Wang, J. Understanding the Impact of Vertical Canopy Position on Leaf Spectra and Traits in an Evergreen Broadleaved Forest. Remote Sens. 2021, 13, 5057. https://doi.org/ $10.3390 /$ rs13245057

Academic Editor: Michael Sprintsin

Received: 10 November 2021

Accepted: 8 December 2021

Published: 13 December 2021

Publisher's Note: MDPI stays neutral with regard to jurisdictional claims in published maps and institutional affiliations.

Copyright: (c) 2021 by the authors. Licensee MDPI, Basel, Switzerland. This article is an open access article distributed under the terms and conditions of the Creative Commons Attribution (CC BY) license (https:/ / creativecommons.org/licenses/by/ $4.0 /)$.
1 School of Geographical Sciences and Remote Sensing, Guangzhou University, Guangzhou 510006, China; yfy@gzhu.edu.cn (F.Y.); zfwu@gzhu.edu.cn (Z.W.)

2 School of Forest Resources, College of Natural Sciences, Forestry, and Agriculture, University of Maine, Orono, ME 04469, USA; tawanda.gara@maine.edu

3 Key Laboratory of Vegetation Restoration and Management of Degraded Ecosystems, South China Botanical Garden, Chinese Academy of Sciences, Guangzhou 510650, China; lianjy@scbg.ac.cn (J.L.); why@scbg.ac.cn (W.Y.)

4 Center of Plant Ecology, Core Botanical Gardens, Chinese Academy of Sciences, Guangzhou 510650, China

5 Southern Marine Science and Engineering Guangdong Laboratory (Guangzhou), Guangzhou 510650, China

6 Guangdong Provincial Key Laboratory of Applied Botany, South China Botanical Garden, Chinese Academy of Sciences, Guangzhou 510650, China

7 Institute of Agricultural Resources and Environment, Guangdong Academy of Agricultural Sciences, Guangzhou 510640, China; shenjian@gdaas.cn

8 Department of Natural Resources, Faculty of Geo-Information Science and Earth Observation, University of Twente, P.O. Box 217, 7500 AE Enschede, The Netherlands; t.wang@utwente.nl

9 College of Life Sciences and Oceanography, Shenzhen University, Shenzhen 518060, China

* Correspondence: wang_2015@szu.edu.cn

Abstract: Little attention has been paid to the impact of vertical canopy position on the leaf spectral properties of tall trees, and few studies have explored the ability of leaf spectra to characterize the variation of leaf traits across different canopy positions. Using a tower crane, we collected leaf samples from three canopy layers (lower, middle, and upper) and measured eight leaf traits (equivalent water thickness, specific leaf area, leaf carbon content, leaf nitrogen content, leaf phosphorus content, leaf chlorophyll content, flavonoid, and nitrogen balance index) in a subtropical evergreen broadleaved forest. We evaluated the variability of leaf traits and leaf spectral properties, as well as the ability of leaf spectra to track the variation of leaf traits among three canopy layers for six species within the entire reflectance spectrum. The results showed that the eight leaf traits that were moderately or highly correlated with each other showed significant differences along the vertical canopy profile. The three canopy layers of leaf spectra showed contrasting patterns for light-demanding (Castanopsis chinensis, Castanopsis fissa, Schima superba, and Machilus chinensis) and shade-tolerant species (Cryptocarya chinensis and Cryptocarya concinna) along the vertical canopy profile. The spectra at the lower and upper canopy layers were more sensitive than the middle layer for tracking the variation of leaf chlorophyll and flavonoid content. Our results revealed that it is important to choose an appropriate canopy layer for the field sampling of tall trees, and we suggest that flavonoid is an important leaf trait that can be used for mapping and monitoring plant growth with hyperspectral remote sensing.

Keywords: canopy layer; hyperspectral; tower crane; tree species; leaf traits

\section{Introduction}

Tree species information provides essential data for biodiversity monitoring and sustainable forest management, and it is also a key parameter of evaluation models of forest growth, health, and yield [1]. Subtropical evergreen broadleaved forests are of great importance to improving the regional ecological environment and maintaining biodiversity [2]. 
However, the dense forest stands and extraordinary species richness in subtropical evergreen broadleaved forests make it difficult to collect leaf samples from the upper canopies of tall trees that match remote sensing data.

Traditionally, obtaining the foliar information of tall trees has been costly, labor intensive, and time consuming [3]. In contrast, remote sensing is an efficient way to monitor forest leaf traits and biodiversity conservation over space and time $[4,5]$. However, when using remote sensing to map and monitor leaf traits, it must be understood that tree species have a unique canopy structure, spectral features, and phenotypic traits [6,7]. In fact, the complex factors (e.g., the phenology, region, plant diseases, and remote sensor) could work together, marking different tree species with similar spectral features. Such inconsistencies between different species could be decreased or avoided by considering both their reflectance spectra and their functional traits related to remote sensing data [8].

Plant functional traits are important parameters that can effectively reflect the growth, reproduction, and survival of plants $[9,10]$, and they are also used to explain the response mechanism of plants to changing environments at the levels of the leaf, canopy, individual, species, community, and landscape [11]. Researchers have widely used plant functional traits to classify plants into different types of species [12]. Among all the functional traits, leaf traits directly reflect how plants adapt to surrounding environments [13] and affect ecosystem functions, because they can partly regulate light absorption efficiency, cellular respiration, and gas exchange [14]. Moreover, leaf traits (e.g., chlorophyll, nitrogen, and water content) are important factors affecting plant leaf and canopy spectral signatures. Field spectroscopy can provide comprehensive spectral information for estimating foliar biochemistry (e.g., chlorophyll and nitrogen), quantifying plant biophysical parameters (e.g., leaf area index and crown density), and identifying plant species [15]. Therefore, understanding the covarying mechanism of vegetation spectra against the properties of plant canopy biochemistry, structure, and phenology is essential to map and monitor the spatial distribution of vegetation species and health using remote sensing.

Generally, empirical (e.g., univariate regression, partial least squares regression, support vector regression, and random forest regression) and physical models (e.g., PROSPECT and PROSAIL) are applied to associate plant reflectance spectra with leaf traits collected in field surveys [4-6]. Many researchers established accurate models with $R^{2}>0.7$ using these modeling methods to quantify leaf traits, and much attention has been paid to the spectra-trait relationship for mature and sunlit leaves of the upper canopy [16]. It is worth noting that these approaches are based on the assumption that leaf spectra and traits within the canopy are consistent and homogeneous. However, the canopy actually displays great heterogeneity of both biophysical and optical properties [17]. In nature, light intensity, temperature, and humidity change profoundly with the vertical gradient from the upper to lower canopy [18]. Leaves at different canopy layers respond to the environment and stress conditions differently in their resource allocation patterns and investment strategies. The leaves located in the upper layer of the canopy receive high radiant energy, which is prone to lack of water, while the light absorption rate of leaves in the lower canopy layer is generally low [19]. The difference in light intensity distribution between canopy layers affects the absorption, utilization, and redistribution of nitrogen $(\mathrm{N})$, phosphorus $(\mathrm{P})$, and other elements of plant leaves. Therefore, assuming that the biophysical and biochemical properties within the vertical canopy are homogenous may lead to systematic errors when establishing the relationship between spectral properties and field-measured leaf traits $[17,20]$. However, most researchers do not focus on the effect of different canopy layers (upper, middle, and lower) on leaf spectra, and little attention has been paid to evaluating the ability of leaf optical properties to characterize the variation of leaf traits among different vertical canopy positions and species within the entire spectrum [21-23].

When exploring either empirical or physical models to associate spectral features with the leaf traits of tall trees, collecting the branches of sunlit leaves is a requirement. In fact, collecting leaves from different canopy positions may affect the relationship between leaf traits and reflectance spectra. Some studies only collected sample data from the lower 
branches and leaves to infer the structure of the upper canopy of tall trees [24]. Moreover, a number of technologies and a variety of equipment, including crossbows [25], ladders, cotton pickers, ultra-lightweight small aircraft, single rope climbing, canopy trails, hot air balloons, canopy rafts, and tower cranes have been used in forest canopy research [26]. However, most of these techniques and technologies can only collect samples from the upper layer of the canopy. In contrast, a crane tower is characterized as 'omnibearing, high-precision, non-destructive, and repeatable' [27], and can provide unique advantages for studying forest structure and collecting samples (i.e., leaf, branch, flower, and fruits) from the bottom to top of the canopy [28]. It can also implement the control experiment of tree physiology [29].

Although Gara et al. [15] investigated the impact of vertical canopy position on leaf spectral properties and traits across multiple species, the study focused on potted plants (height $<1 \mathrm{~m}$ ) grown in an experimental room. Hence, it is important to examine how leaf traits vary across the vertical canopy in trees $(>4 \mathrm{~m})$ growing in a natural environment without human disturbance. Using the tower crane technology in a subtropical evergreen forest, we aimed to sample foliage material across the canopy and explore the effect of vertical canopy position on leaf optical properties and traits in a mature forest. Specifically, we evaluate the ability of leaf spectra to track the variation of leaf traits across the vertical canopy position in a subtropical evergreen forest. This study could assist in sampling protocols using technology such as tower cranes for remote sensing of leaf traits across different canopy layers, which might provide insights for understanding the vertical differences in the ecological and biological processes of tall and dense forests.

\section{Materials and Methods}

\subsection{Study Area}

The study (tower crane plot) was conducted in Dinghushan Nature Reserve (DHS) in Guangdong Province, southern China $\left(23^{\circ} 09^{\prime} 21^{\prime \prime}-23^{\circ} 11^{\prime} 30^{\prime \prime} \mathrm{N}, 112^{\circ} 30^{\prime} 39^{\prime \prime}-112^{\circ} 33^{\prime} 41^{\prime \prime} \mathrm{E}\right)$ (Figure 1). The reserve is dominated by a typical subtropical monsoon evergreen broadleaved forest with a mean annual temperature of $20.9{ }^{\circ} \mathrm{C}$ and mean annual precipitation of $1927 \mathrm{~mm}$ [30]. The elevation of the reserve ranges from 14 to $1000 \mathrm{~m}$, and the soil type is lateritic red earth, yellow earth, and mountain shrubby-meadow soil. The tower crane plot (1.44 ha, $120 \mathrm{~m} \times 120 \mathrm{~m}$ ) was constructed in 2014, following the protocols from the CTFS-ForestGEO network [31]. We collected leaf samples with the tower, which is $60 \mathrm{~m}$ high, with a boom arm that is $60 \mathrm{~m}$ long.

\subsection{Field Sampling}

There are approximately 4879 trees in the tower crane plot. The field work was carried out between 7:30 a.m. and 10:00 a.m. during the sunny days of 10-13 August 2019 using stratified random sampling. We selected six dominant species (Castanopsis chinensis (Castch), Castanopsis fissa (Castfi), Cryptocarya chinensis (Crypch), Cryptocarya concinna (Crypco), Machilus chinensis (Machch), and Schima superba (Schisu)) with 89 trees in this plot. For each sampled tree, we divided the tree into three layers based on average height [32]. These layers are upper layer ( $>11.3 \mathrm{~m}$ from the ground), middle layer (4$11.3 \mathrm{~m}$ from the ground), and lower layer ( $<4 \mathrm{~m}$ from the ground) (Figure 2). Based on the standardized specification for measuring plant functional traits as described by Cornelissen et al. [33], we randomly chose 12-20 mature and healthy individual trees for each species. For each of the selected 89 trees (Table 1), we collected 15-30 mature and healthy leaves from the lower, middle, and upper canopy, respectively. For each of the 267 samples ( 89 trees $\times$ three canopy layers), the collected fresh leaves were placed in a valve bag after collection. The samples were transported to the lab to measure their fresh weight, leaf area, and leaf spectral reflectance within four hours of collection. 


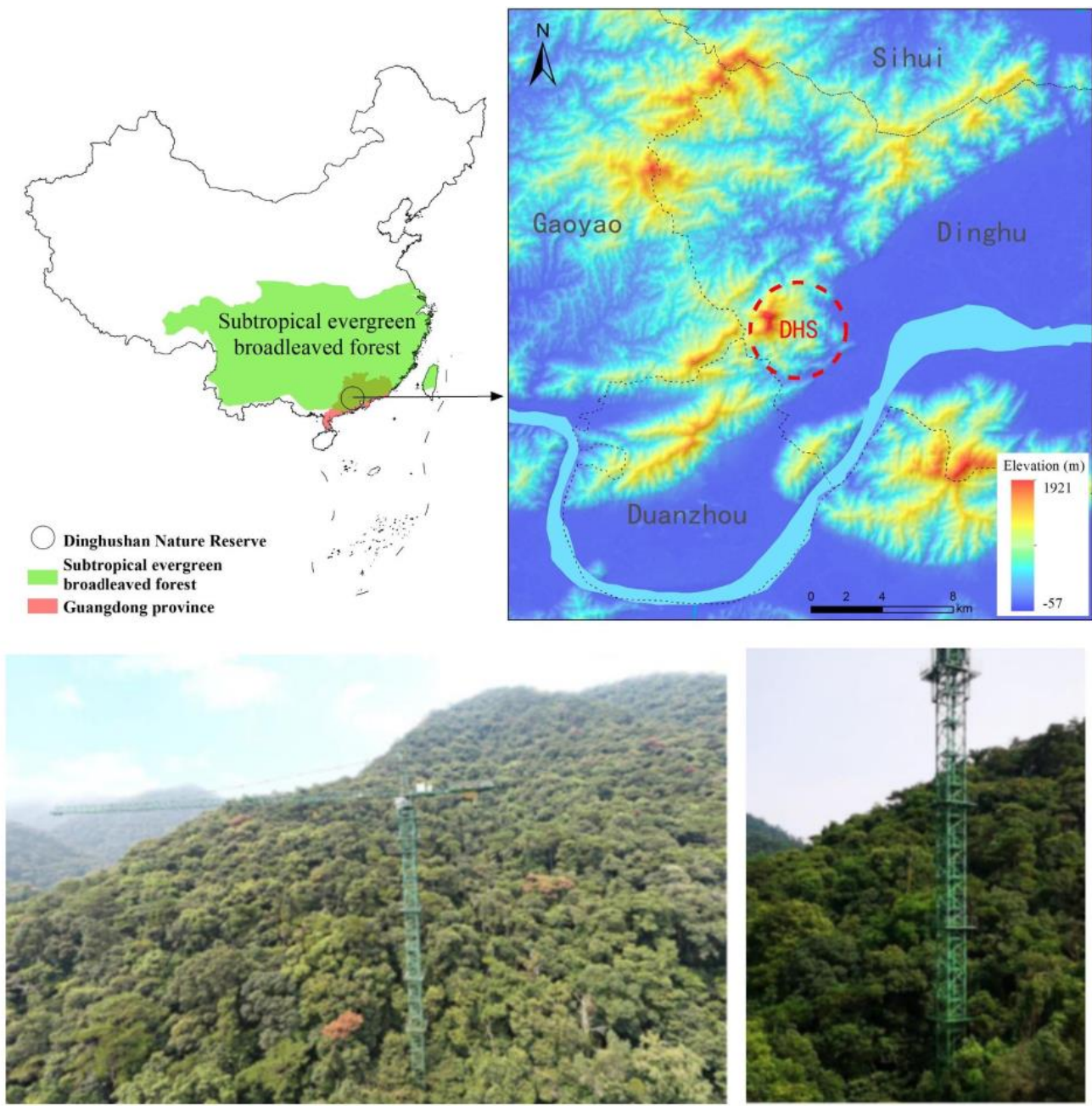

Figure 1. Location of study area (above) and picture of tower crane plot (below) in Dinghushan Nature Reserve (DHS), China.

Table 1. Photo and sample size of six dominant species.

\begin{tabular}{|c|c|c|c|c|c|}
\hline Photo & $\begin{array}{c}\text { Species } \\
\text { Name }\end{array}$ & Size & Photo & $\begin{array}{c}\text { Species } \\
\text { Name }\end{array}$ & Size \\
\hline & $\begin{array}{c}\text { Castanopsis } \\
\text { chinensis }\end{array}$ & 12 & & $\begin{array}{c}\text { Cryptocarya } \\
\text { concinna }\end{array}$ & 13 \\
\hline & $\begin{array}{c}\text { Castanopsis } \\
\text { fissa }\end{array}$ & 15 & & $\begin{array}{l}\text { Machilus } \\
\text { chinensis }\end{array}$ & 20 \\
\hline & $\begin{array}{l}\text { Cryptocarya } \\
\text { chinensis }\end{array}$ & 13 & & $\begin{array}{l}\text { Schima } \\
\text { superba }\end{array}$ & 16 \\
\hline
\end{tabular}




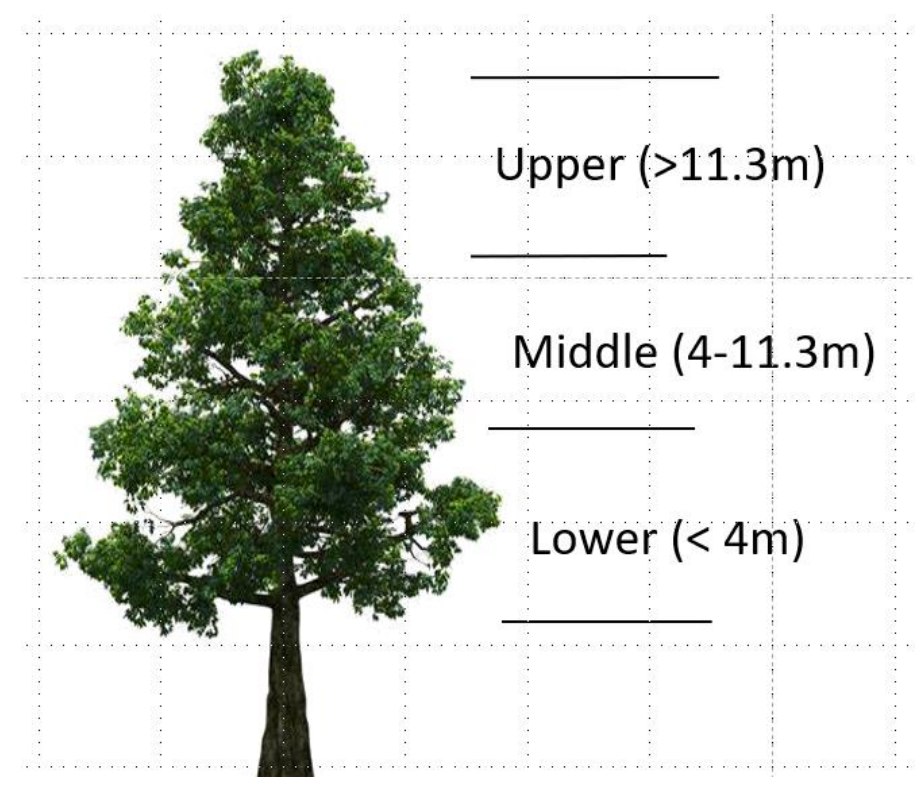

Figure 2. Illustration of the three canopy layers.

\subsection{Measurement of Leaf Traits}

In this study, we selected eight widely used leaf traits, including six area-based (equivalent water thickness, specific leaf area, leaf carbon content, leaf nitrogen content, leaf phosphorus content, and leaf chlorophyll content) and two mass-based (flavonoid and nitrogen balance index) traits (Table 2). The area-based leaf traits are important for physicochemical processes associated with vegetation photosynthesis and carbon sequestration, while the mass-based traits are important for leaf hydraulics and economy [25].

The leaf traits were measured according to the standard method depicted in the functional trait collection manual of Cornelissen et al. [33]. In the field, we measured SPAD values of fresh leaves using a portable SPAD-502 Chlorophyll Meter (Minolta, Inc., Japan), and the mean SPAD value (M, unitless) was recorded for each sample. Afterwards, we converted the mean SPAD value to area-based leaf chlorophyll content $\left(\mathrm{CHL}_{\text {area, }}\right.$, unit: $\left.\mu \mathrm{g} / \mathrm{cm}^{2}\right)$ with an empirical transformation model $\left(\mathrm{CHL}_{\text {area }}=10^{M^{0.265}}\right)$ that was proposed by Markwell et al. [34]. Additionally, the flavonoid and nitrogen balance index (NBI) were measured with a Dualex Scientific+ (Force-A, Orsay, France) meter.

Before we measured the leaf traits, the petiole of each collected leaf was removed with a pair of scissors. The fresh weight of each leaf sample was measured with a high-precision $(0.001 \mathrm{~g})$ digital scale. Leaf surface area was recorded with a LI-3000C Portable Area Meter (LI-COR, Inc., Lincoln, NE, USA). Afterwards, the fresh samples were dried at $65^{\circ} \mathrm{C}$ for $48 \mathrm{~h}$ in an oven, and the dry weight was measured with the digital scale. The equivalent water thickness (EWT) and leaf mass per area (LMA) were calculated based on fresh weight, dry weight, and leaf surface area. The dried leaves were grounded into powder using a mortar, stored in paper bags, and subsequently sent to an analytical laboratory to measure the chemical parameters (carbon, nitrogen, and phosphorus content). The summary statistics of the eight leaf traits measured in the laboratory are presented in Table 2. 
Table 2. Eight functional traits measured in this study.

\begin{tabular}{|c|c|c|c|c|c|}
\hline Fun & onal Trait & Abbr. & Unit & Method & Notes \\
\hline \multirow{6}{*}{ Area-based } & $\begin{array}{c}\text { Equivalent water } \\
\text { thickness }\end{array}$ & EWT & $\mathrm{cm}$ & $\left(\mathrm{W}_{\mathrm{f}}-\mathrm{W}_{\mathrm{d}}\right) / \mathrm{A}$ & $\begin{array}{l}\text { A highly dynamic component of the } \\
\text { plant canopy related to structural and } \\
\text { other biochemical changes, responding } \\
\text { quickly to heterogeneity in timing and } \\
\text { quantity of precipitation and associated } \\
\text { soil moisture. }\end{array}$ \\
\hline & $\begin{array}{l}\text { Leaf carbon } \\
\text { content }\end{array}$ & $\mathrm{C}_{\text {area }}$ & $\mathrm{g} / \mathrm{cm}^{2}$ & $\mathrm{C}_{\text {mass }} \times \mathrm{LMA}$ & $\begin{array}{c}\text { Related to photosynthetic rate and } \\
\text { nutrient storage of plants, reflecting } \\
\text { plant growth and physiological } \\
\text { mechanism regulation. }\end{array}$ \\
\hline & $\begin{array}{l}\text { Leaf nitrogen } \\
\text { content }\end{array}$ & $N_{\text {area }}$ & $\mathrm{g} / \mathrm{cm}^{2}$ & $\mathrm{~N}_{\text {mass }} \times \mathrm{LMA}$ & Indication of plant health and growth. \\
\hline & $\begin{array}{l}\text { Leaf phosphorus } \\
\text { content }\end{array}$ & $P_{\text {area }}$ & $\mathrm{g} / \mathrm{cm}^{2}$ & $P_{\text {mass }} \times$ LMA & $\begin{array}{l}\text { Important parameter reflecting plant } \\
\text { health and growth. }\end{array}$ \\
\hline & Specific leaf area & SLA & $\mathrm{cm}^{2} / \mathrm{g}$ & $\begin{array}{l}\text { Leaf surface area / } \\
\text { leaf dry mass }\end{array}$ & Plant light capture and carbon gain. \\
\hline & $\begin{array}{l}\text { Leaf chlorophyll } \\
\text { content }\end{array}$ & $\mathrm{CHL}_{\text {area }}$ & $\mu \mathrm{g} / \mathrm{cm}^{2}$ & $10^{M^{0.265}}$ & $\begin{array}{l}\text { Important parameter reflecting plant } \\
\text { health and growth. }\end{array}$ \\
\hline \multirow[t]{2}{*}{ Mass-based } & Flavonoid & Flav & - & $\begin{array}{l}\text { Dualex scientific } \\
\text { meter }\end{array}$ & $\begin{array}{l}\text { Regulating plant growth under } \\
\text { different intensities of sunlight } \\
\text { irradiance. }\end{array}$ \\
\hline & $\begin{array}{l}\text { Nitrogen balance } \\
\text { index }\end{array}$ & NBI & - & $\begin{array}{l}\text { Dualex scientific } \\
\text { meter }\end{array}$ & $\begin{array}{l}\text { Indication of leaf nitrogen content and } \\
\text { plant growth. }\end{array}$ \\
\hline
\end{tabular}

$\mathrm{W}_{\mathrm{f}}, \mathrm{W}_{\mathrm{d}}$, and $\mathrm{A}$ are leaf fresh weight (unit: $\mathrm{g}$ ), dry weight (unit: $\mathrm{g}$ ), and leaf area (unit: $\mathrm{cm}^{2}$ ), respectively. Leaf surface area $(\mathrm{LMA})=\mathrm{W}_{\mathrm{d}} / \mathrm{A}$.

\subsection{Spectral Reflectance Measurement and Preprocessing}

An ASD FieldSpec 4 portable spectroradiometer (Analytical Spectral Devices, Inc., Boulder, CO, USA) was employed to collect the spectral reflectance of fresh leaf samples. The spectroradiometer has a total of 2151 wavebands $(350-2500 \mathrm{~nm})$ with a sampling interval of $1.4 \mathrm{~nm}$ ranging from 350 to $1000 \mathrm{~nm}$ and $2 \mathrm{~nm}$ ranging from 1000 to $2500 \mathrm{~nm}$. For each sample, we randomly chose ten individual leaves and measured their reflectance spectra using an ASD fitted leaf clip and plant probe; the final leaf spectrum of each sample was the mean spectrum of the ten selected leaves. Because there are large systematic noises in the range of 350-399 $\mathrm{nm}$ and $2451-2500 \mathrm{~nm}$, we reduced the original leaf spectra to $400-2450 \mathrm{~nm}$ to enhance the signal-to-noise ratio.

\subsection{Statistical Analysis}

We calculated the variation of leaf traits and spectra with the dataset of individual species and their pooled dataset, respectively. The impact of different canopy positions on leaf spectra and traits was explored using a one-way analysis of variance (ANOVA). Based on the significant ANOVA test, we then employed Tukey's honestly significant difference (HSD) post-hoc tests with leaf spectra and traits, respectively. To evaluate the patterns of trait-trait covariation, we used pairwise bivariate correlations among the eight leaf traits. The correlations of the eight leaf traits against leaf spectra were calculated and compared. The software R (version 3.4.1) was used to carry out all the statistical analyses.

\section{Results}

\subsection{Variation of Leaf Traits along the Vertical Canopy Profile}

With the pooled dataset, Flav, EWT, $\mathrm{CHL}_{\text {area }}, \mathrm{C}_{\text {area }}, \mathrm{N}_{\text {area }}$, and $\mathrm{P}_{\text {area }}$ values tended to increase from the bottom to the upper layer, while NBI and SLA values showed a decreasing trend from the bottom to the upper layer (Table 3). The leaf traits along the vertical canopy for the six individual species showed similar statistical patterns with the pooled data (Figure 3). The ANOVA test showed that almost all the leaf traits of Castch had significant differences $(p<0.05)$ across the vertical canopy profile. Six leaf traits $\left(\mathrm{C}_{\text {area }}\right.$, Flav, 
$\mathrm{N}_{\text {area, }}$ NBI, $\mathrm{P}_{\text {area, }}$ and SLA) of Schisu had significant differences across the vertical canopy profile. Meanwhile, only Flav of Machch and $\mathrm{CHL}_{\text {area }}$ of Castch demonstrated significant differences, and the other leaf traits of these two species did not have significant variation.
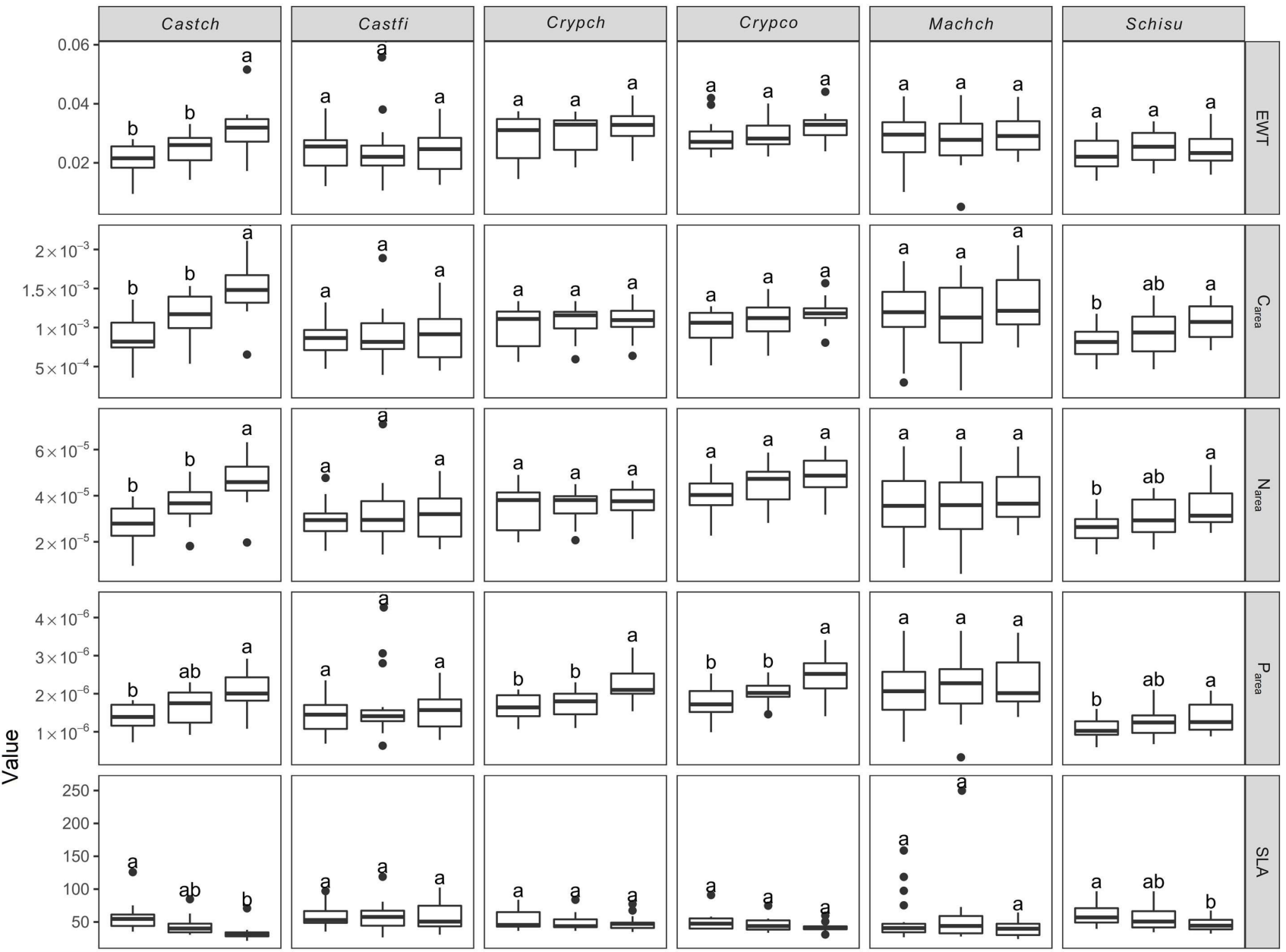

$\frac{2}{5}$
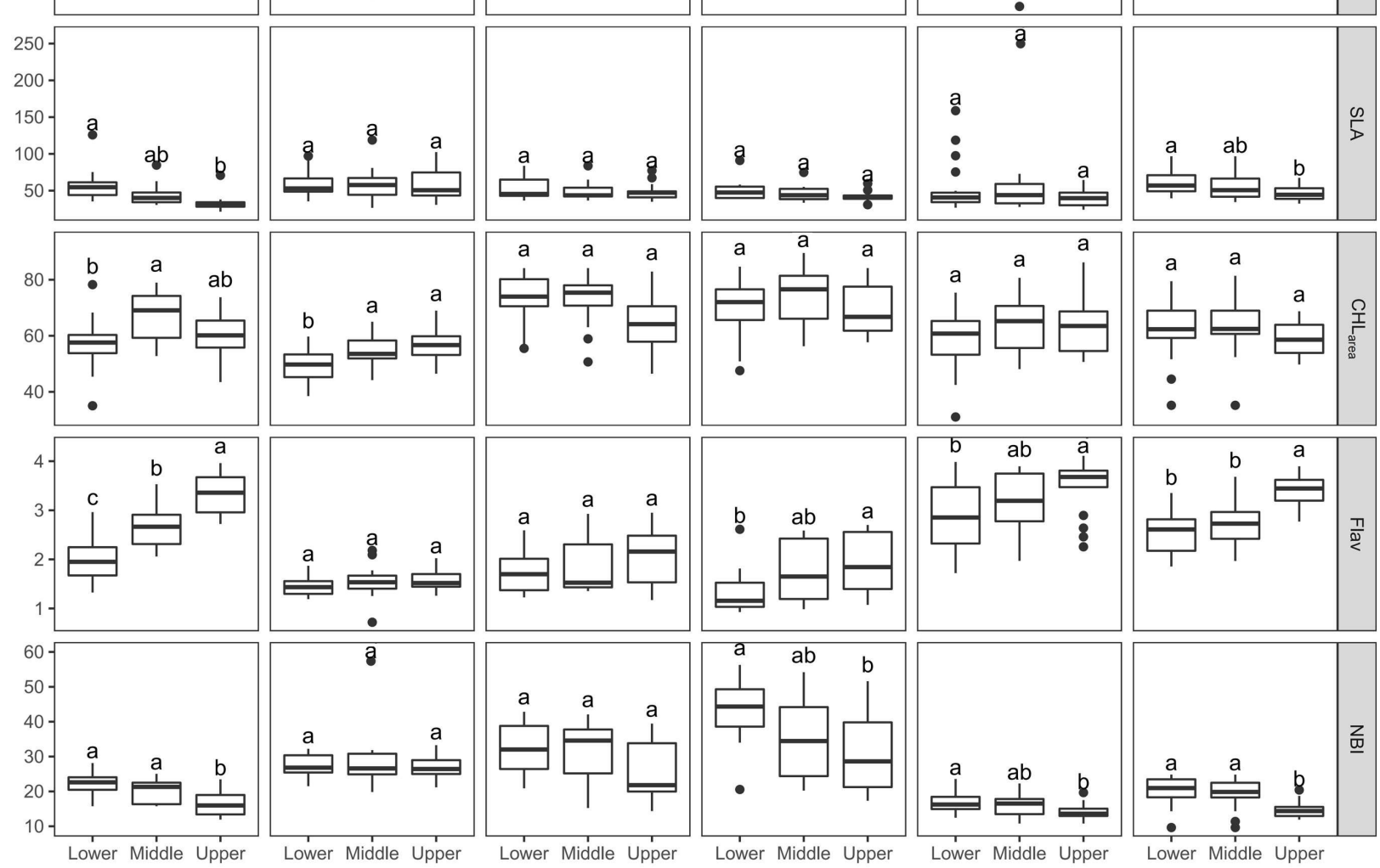

Figure 3. Variation of leaf traits across three canopy layers for six species. Different letters (a, b, c, and ab) indicate a significant difference $(p<0.05)$ between the values of leaf traits. 
Table 3. Statistics of leaf traits across three canopy layers.

\begin{tabular}{|c|c|c|c|c|c|c|c|c|c|c|}
\hline \multirow{2}{*}{\multicolumn{2}{|c|}{ Leaf Trait }} & \multicolumn{3}{|c|}{ Lower Layer $(n=89)$} & \multicolumn{3}{|c|}{ Middle Layer $(n=89)$} & \multicolumn{3}{|c|}{ Upper Layer $(n=89)$} \\
\hline & & Range & Mean & SD & Range & Mean & SD & Range & Mean & SD \\
\hline \multirow{6}{*}{$\begin{array}{l}\text { Area- } \\
\text { based }\end{array}$} & EWT (cm) & $\begin{array}{c}0.0095- \\
0.0425\end{array}$ & 0.0256 & 0.0079 & $\begin{array}{c}0.0051- \\
0.0558\end{array}$ & 0.0271 & 0.0079 & $\begin{array}{l}0.0126- \\
0.0516\end{array}$ & 0.0289 & 0.0075 \\
\hline & $\begin{array}{c}\text { Carea } \\
\left(\mathrm{g} / \mathrm{cm}^{2}\right)\end{array}$ & $\begin{array}{c}(0.297- \\
1.85) \\
\times 10-3\end{array}$ & $\begin{array}{l}9.67 \\
\times 10-4\end{array}$ & $\begin{array}{c}3.16 \\
\times 10-4\end{array}$ & $\begin{array}{c}(0.196- \\
1.89) \\
\times 10-3\end{array}$ & $\begin{array}{c}1.06 \\
\times 10-3\end{array}$ & $\begin{array}{c}3.33 \\
\times 10-4\end{array}$ & $\begin{array}{c}(0.449- \\
2.11) \\
\times 10-3\end{array}$ & $\begin{array}{c}1.17 \\
\times 10-3\end{array}$ & $\begin{array}{c}3.55 \\
\times 10-4\end{array}$ \\
\hline & $\begin{array}{c}\text { Narea } \\
\left(\mathrm{g} / \mathrm{cm}^{2}\right)\end{array}$ & $\begin{array}{c}(0.876- \\
6.14) \\
\times 10-5\end{array}$ & $\begin{array}{l}3.21 \times \\
10-5\end{array}$ & $\begin{array}{l}1.12 \times \\
10-5\end{array}$ & $\begin{array}{c}(0.612- \\
7.10) \\
\times 10-5\end{array}$ & $\begin{array}{l}3.56 \\
\times 10-5\end{array}$ & $\begin{array}{c}1.15 \\
\times 10-5\end{array}$ & $\begin{array}{c}(0.168- \\
6.32) \\
\times 10-5\end{array}$ & $\begin{array}{c}3.91 \\
\times 10-5\end{array}$ & $\begin{array}{c}1.16 \\
\times 10-5\end{array}$ \\
\hline & $\begin{array}{c}\text { Parea } \\
\left(\mathrm{g} / \mathrm{cm}^{2}\right)\end{array}$ & $\begin{array}{c}(0.595- \\
3.65) \\
\times 10-6\end{array}$ & $\begin{array}{l}1.58 \times \\
10-6\end{array}$ & $\begin{array}{c}6.00 \times \\
10-7\end{array}$ & $\begin{array}{c}(0.330- \\
4.26) \\
\times 10-6\end{array}$ & $\begin{array}{c}1.77 \\
\times 10-6\end{array}$ & $\begin{array}{c}6.70 \\
\times 10-7\end{array}$ & $\begin{array}{c}(0.787- \\
3.60) \\
\times 10-6\end{array}$ & $\begin{array}{c}1.99 \\
\times 10-6\end{array}$ & $\begin{array}{c}6.73 \\
\times 10-7\end{array}$ \\
\hline & $\begin{array}{c}\text { SLA } \\
\left(\mathrm{cm}^{2} / \mathrm{g}\right)\end{array}$ & $\begin{array}{l}26.80- \\
158.77\end{array}$ & 55.95 & 22.53 & $\begin{array}{l}26.91- \\
248.98\end{array}$ & 52.18 & 26.84 & $\begin{array}{l}21.38- \\
102.43\end{array}$ & 45.32 & 14.93 \\
\hline & $\begin{array}{l}\text { CHLarea } \\
\left(\mu \mathrm{g} / \mathrm{cm}^{2}\right)\end{array}$ & $\begin{array}{l}31.03- \\
91.11\end{array}$ & 61.33 & 12.78 & $\begin{array}{l}35.19- \\
89.54\end{array}$ & 65.44 & 11.05 & $\begin{array}{l}43.49- \\
96.47\end{array}$ & 62.27 & 9.87 \\
\hline \multirow{2}{*}{$\begin{array}{l}\text { Mass- } \\
\text { based }\end{array}$} & Flav & $0.93-3.98$ & 2.08 & 0.76 & $0.72-3.90$ & 2.35 & 0.8 & $1.07-4.11$ & 2.69 & 0.93 \\
\hline & NBI & $\begin{array}{l}9.64- \\
56.28\end{array}$ & 25.85 & 10.14 & $\begin{array}{l}9.64- \\
57.40\end{array}$ & 24.38 & 9.86 & $\begin{array}{l}10.80- \\
56.61\end{array}$ & 20.96 & 8.99 \\
\hline
\end{tabular}

Range: minimum value-maximum value; SD: standard deviation.

\subsection{Correlation between Leaf Traits across the Vertical Canopy Profile}

Most leaf traits (except Flav and NBI) were moderately or highly correlated with the others using the pooled data across the vertical canopy profile (Figure 4). Specifically, EWT, $\mathrm{C}_{\text {area }}, \mathrm{N}_{\text {area }}, \mathrm{P}_{\text {area, }}$ and CHL $\mathrm{L}_{\text {area }}$ were positively correlated $(0.211<r<0.908)$ with each other, while SLA showed a negative correlation with the other leaf traits $(-0.627<r<$ -0.822). SLA has the highest correlation with the other traits at the upper layer, while the correlation between $\mathrm{CHL}_{\text {area }}$ and the other traits decreased from the lower to the upper layer.

The mutual correlations among the traits (EWT, $\mathrm{C}_{\text {area }}, \mathrm{N}_{\text {area }}, \mathrm{P}_{\text {area }}$, and SLA) showed similar trends (Figure S1 in the Supplementary Material). Moreover, Flav showed a moderate correlation with the other traits for Castch, Castfi, Machch and Schisu, but an extremely weak correlation for the other two species. Moreover, the correlations between $\mathrm{CHL}_{\text {area }}$ and the other traits were moderate only for Castch, Machch, and Schisu. 

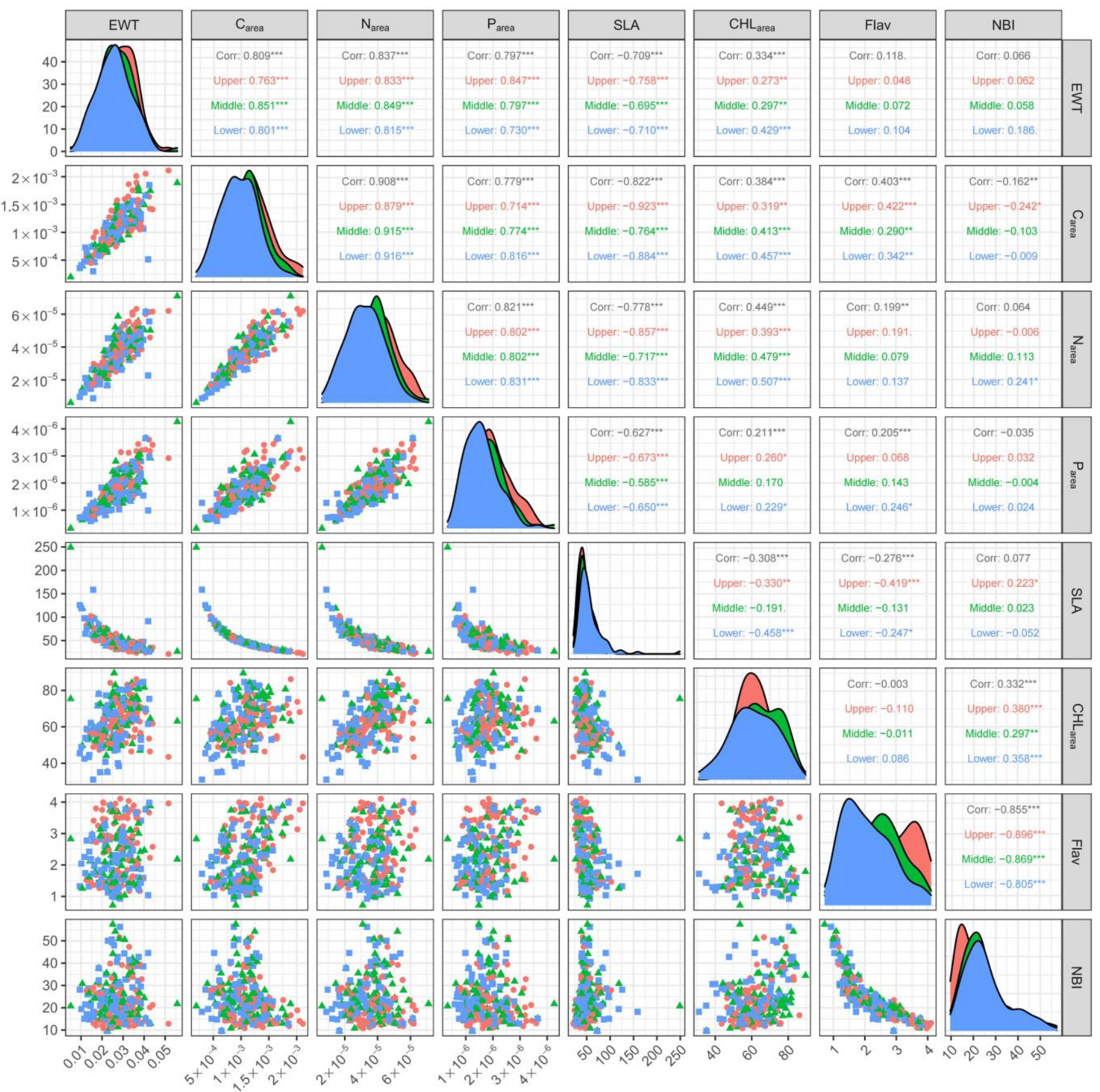

Figure 4. Pairwise scatter plots and mutual correlation of the eight leaf traits (EWT, $\mathrm{C}_{\text {area }}, \mathrm{N}_{\text {area }}, \mathrm{P}_{\text {area }}, \mathrm{SLA}_{1} \mathrm{CHL}_{\mathrm{area}}$, Flav, and NBI) with the pooled dataset. The upper-right panel shows the pairwise pooled data set and correlation coefficients of three layers. The symbols ${ }^{* * *}, * *$ and ${ }^{*}$ represent significance at the $0.001,0.01$, and 0.05 levels, respectively.

\subsection{Effect of Vertical Canopy Position on Leaf Spectra}

In the shortwave infrared (SWIR) region (1400-2450 nm), leaf reflectance tended to increase from the upper to lower layer (Figure 5). The three layers had relatively low reflectance at the wavelengths of 1400 and $1950 \mathrm{~nm}$, and relatively high reflectance at the wavelengths of 1600 and $2200 \mathrm{~nm}$.

The pairwise difference in leaf spectra showed significant differences in the three layers in the spectral region of 750-850 $\mathrm{nm}$ and 1400-2450 nm (Figure 6). The upper and lower layer had significant differences in the range of $1400-2450 \mathrm{~nm}$, but there were no 
significant differences in the range of 1500-1900 $\mathrm{nm}$ between the middle and lower layer (Figure 6).

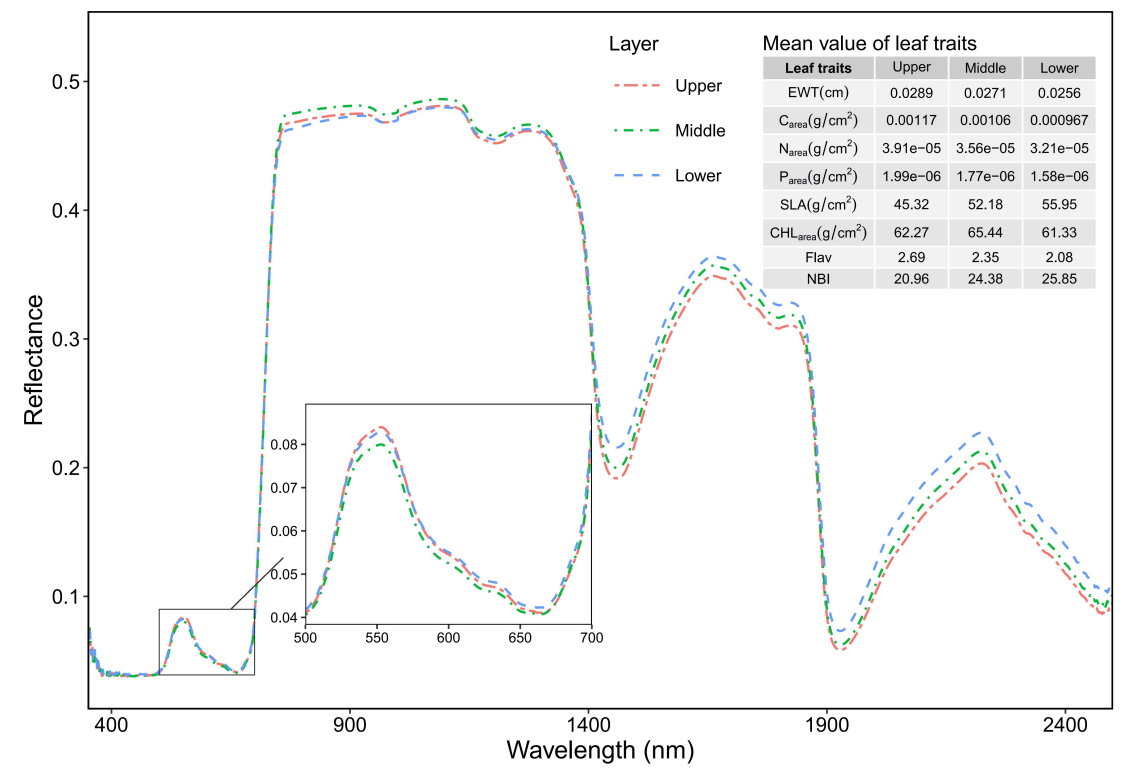

Figure 5. Mean value of leaf reflectance across different canopy layers (lower, middle, and upper) with the pooled dataset.

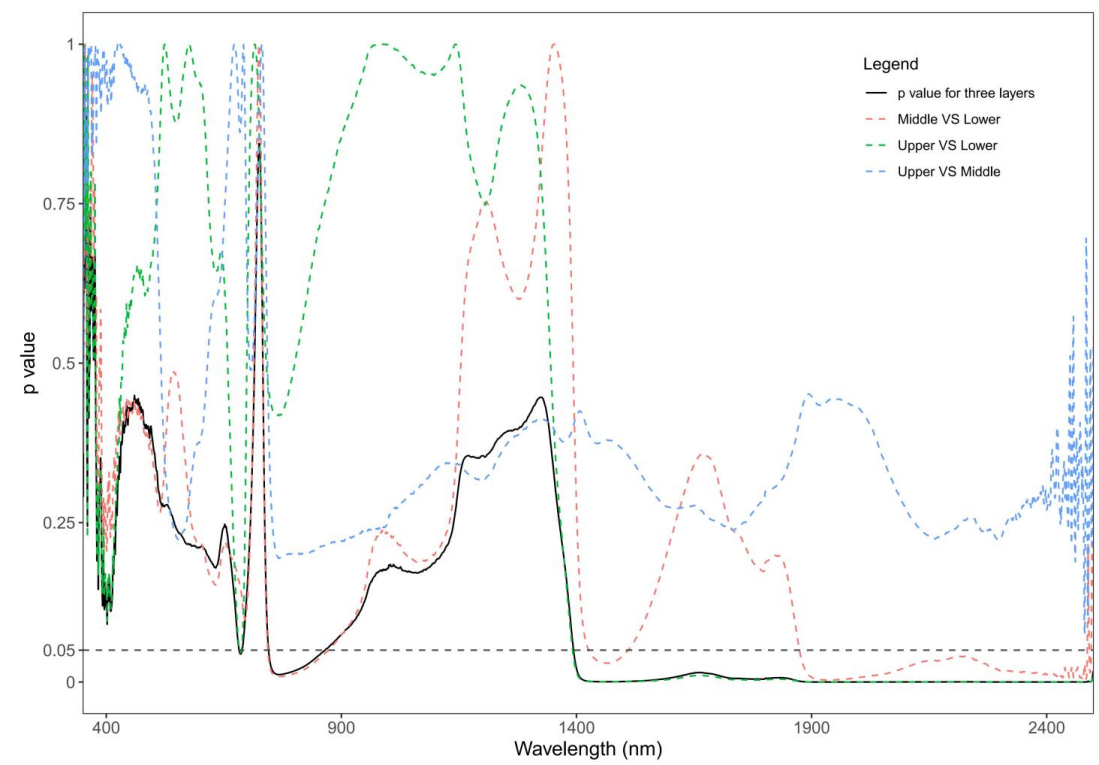

Figure 6. Variation of leaf spectra across different canopy layers with the pooled dataset (ANOVA test), and pairwise variation of leaf spectra across different canopy layers.

In terms of the spectral response among the six species (Figure 7), in the visible region (400-760 nm), Crypch, Crypco, and Machch had a descending mean spectral reflectance from the upper to lower layer, while Castch and Castfi had an ascending pattern. In the shortwave infrared (SWIR) region (1400-2400 nm), the leaf spectral reflectance of six species was uniformly lower for the upper canopy layer (lower $>$ middle $>$ upper) at the wavelengths of 1400-2450 nm, while relevantly low reflectance also appeared at the wavelengths of 1450 and $1900 \mathrm{~nm}$, and high reflectance at the wavelengths of $1600 \mathrm{~nm}$ and $2200 \mathrm{~nm}$. Moreover, among the three canopy layers, there were no significant differences $(p>0.05)$ in spectral reflectance in the visible region $(400-700 \mathrm{~nm})$ for all the six species 
(Figure 8), the leaf samples of Castfi and Machch had nearly no significant differences in their reflectance signatures in the region of 700-2500 nm, the leaf samples of Castch and Schisu reported significant differences $(p<0.05)$ in their reflectance signatures in the region of 710-2450 nm, and the leaf samples of Crypch and Crypco had significant differences in their reflectance signatures in the region of $1850-2450 \mathrm{~nm}$.
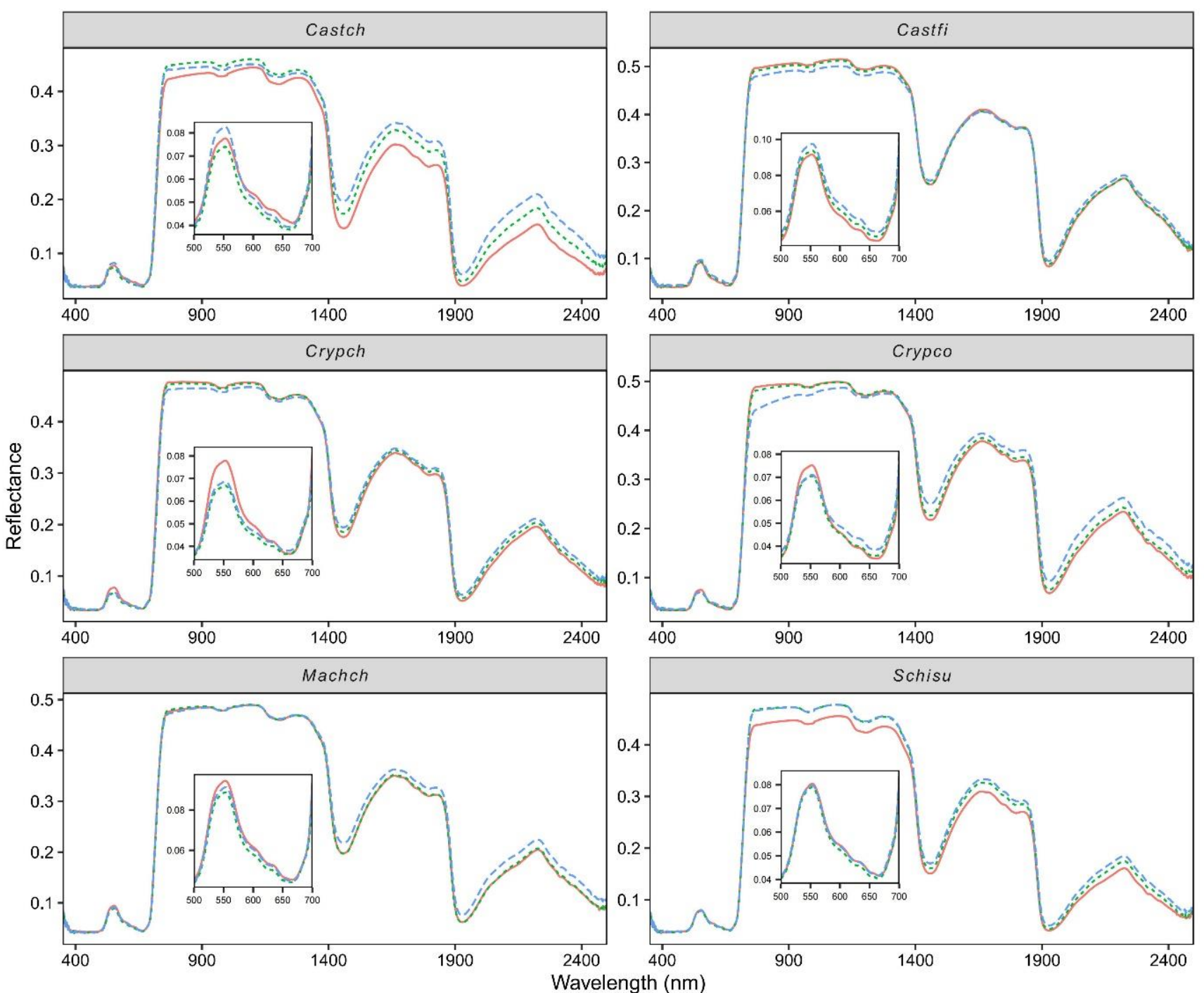

$$
\text { Layer - Upper -... Middle --. Lower }
$$

Figure 7. Species-specific mean leaf spectral reflectance along the vertical canopy profile for the six species. 


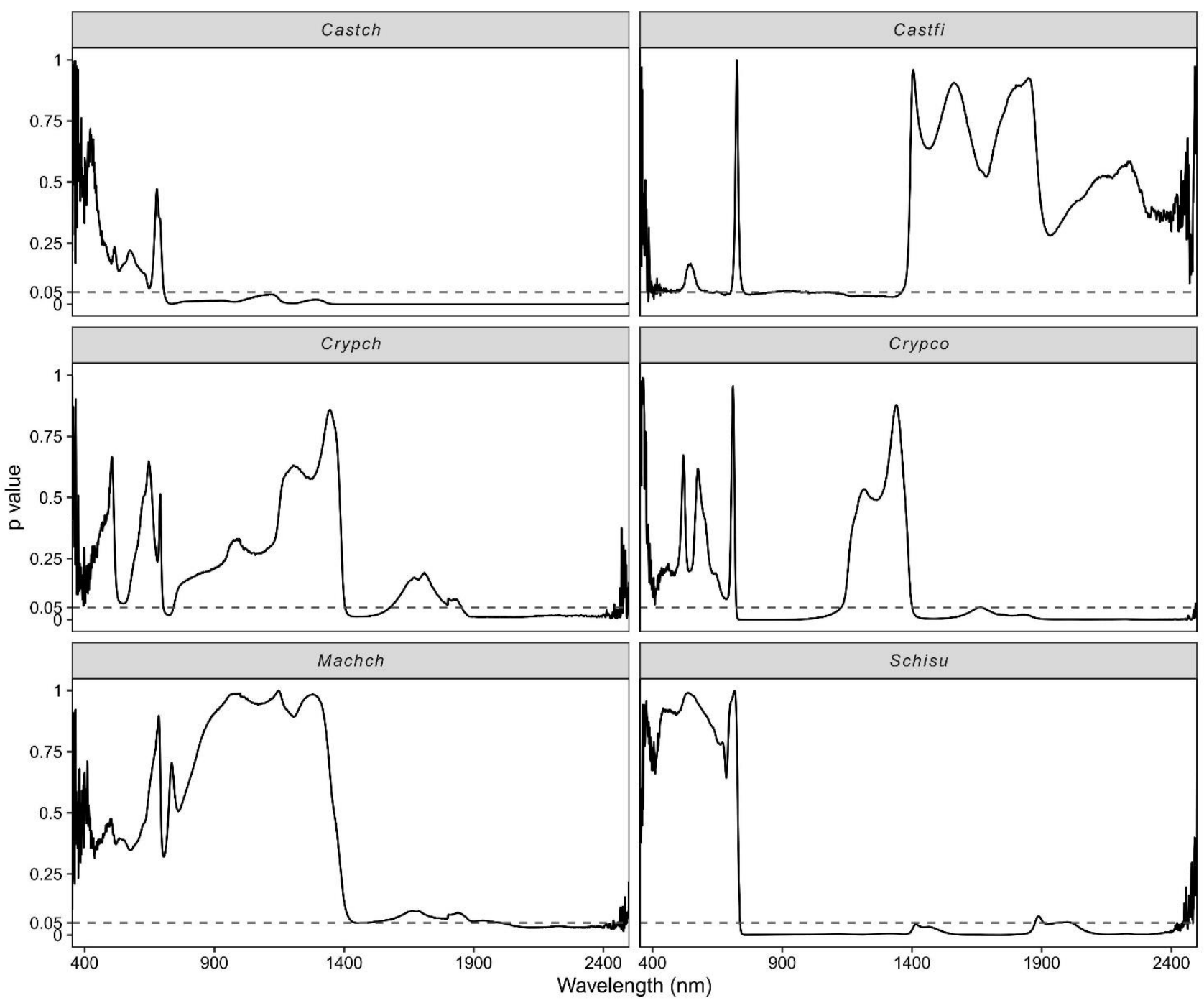

Figure 8. The significant differences $(p<0.05)$ in the reflectance signatures of six species across upper, middle, and lower canopy layers.

\subsection{Response of Spectral Reflectance to Leaf Traits across Different Canopy Layers}

The relationship between spectral reflectance and leaf traits varied along the vertical canopy profile (Figure 9), and the lower layer had the strongest correlation within the whole spectral range for most of the leaf traits. The spectral reflectance against $\mathrm{C}_{\text {area }}$, Flav, NBI, and SLA showed a descending correlation in the order of upper $>$ middle $>$ lower, while $\mathrm{CHL}_{\text {area }}$, EWT, and $\mathrm{N}_{\text {area }}$ showed an ascending correlation for the pooled dataset.

The lower layer of EWT was more sensitive at the wavelengths of 970, 1200, 1450, 1950 , and $2250 \mathrm{~nm}$. The lower layer of $C H L_{\text {area }}$ showed the highest correlation $\left(R^{2}=0.6\right)$ at the wavelengths of 529-540 $\mathrm{nm}$. The upper layer was sensitive to SLA, Flav, and NBI in the range of $1400-1850$ and $1900-2100 \mathrm{~nm}$. 

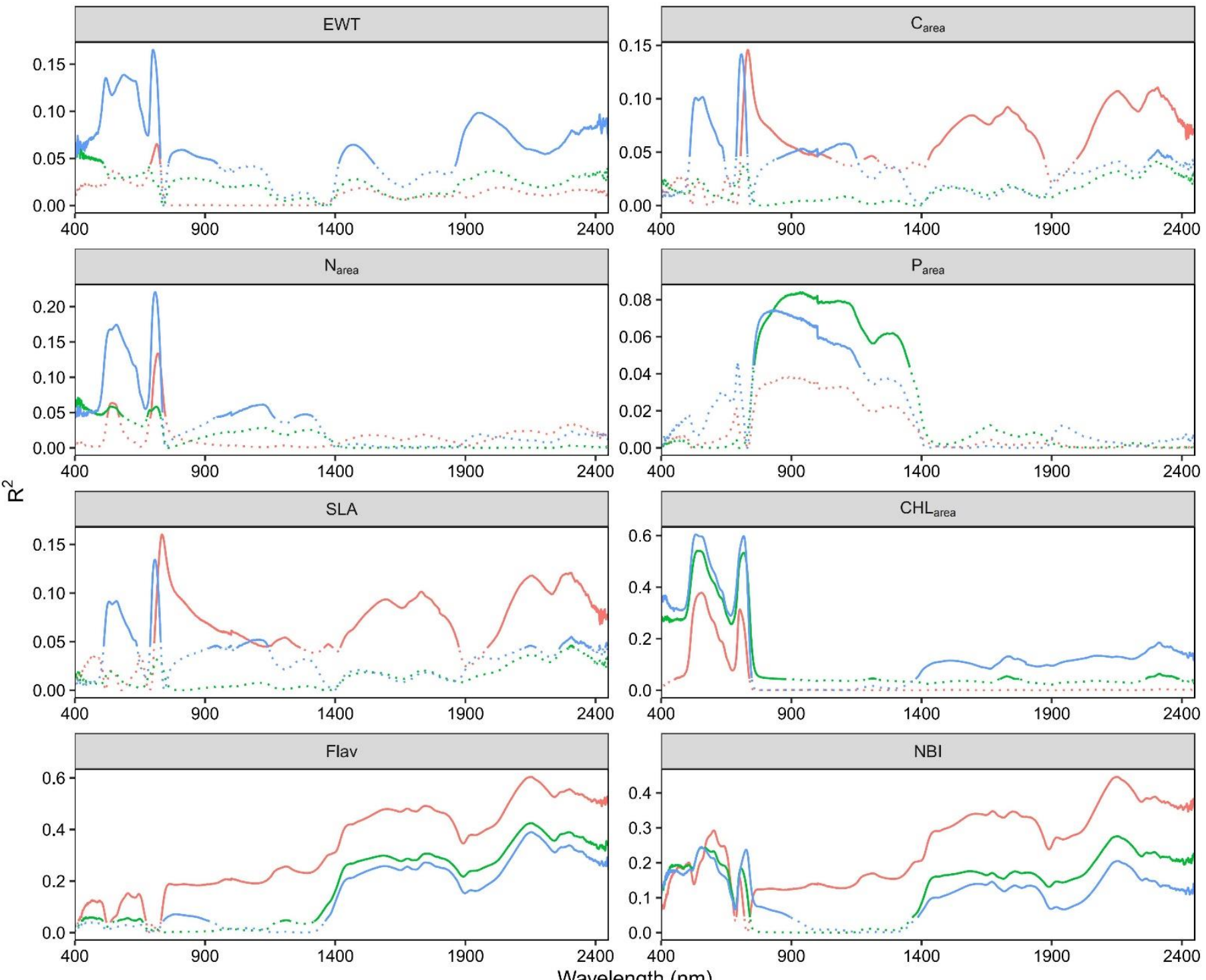

Layer - Upper — Middle - Lower

Figure 9. Correlation $\left(\mathrm{R}^{2}\right)$ between spectral reflectance and eight leaf traits with the pooled dataset across the vertical canopy profile. The solid line suggests the correlation is significant $(p<0.05)$, and the dashed line suggests the correlation is not significant $(p>0.05)$.

\section{Discussion}

\subsection{Effect of Canopy Position on Intraspecific and Interspecific Leaf Traits}

The theoretical trait-based research of plant ecology generally assumes that differences in leaf traits are smaller within species than between species [35], but our results showed that leaf traits had significant discrepancies not only between species, but also within species along the vertical canopy.

The interspecific differences can be explained by the fact that Castch, Castfi, and Schisu are light-demanding species, while the other species are shade-tolerant species, and the two kinds of species have different resource allocation strategies. The lightdemanding species have a relatively well-developed stratum corneum and a large number of stomata, leading to a high proportion of photosynthetic tissue and a high growth rate [36]. The shade-tolerant species tend to adopt conservative resource strategies, with a higher chlorophyll content and a lower specific leaf area than the light-demanding species. 
This was confirmed by our results (Figure 3). Moreover, the shade-tolerant species also face stronger competition for habitat resources, and they maintain higher light resource acquisition and a low mortality rate when the light intensity is weak [37].

Our results showed that Flav, EWT, $\mathrm{CHL}_{\text {area }}, \mathrm{C}_{\text {area }}, \mathrm{N}_{\text {area }}$, and $\mathrm{P}_{\text {area }}$ increased while SLA and NBI decreased from the lower to upper canopy layer for Castch and Schisu. The reason for the significant differences between intraspecific species could be related to the plasticity and genetic variation of plants in response to environmental factors, such as light, water, and nutrients [13]. The differences in organ morphology and the distribution of nutrient elements are important manifestations of adaptation to the environment [27]. Our results demonstrated that SLA decreased from the lower layer to the upper layer, which is consistent with previous studies [38]. The trend can be explained by the adaptation to light. Light usually exhibits gradient changes along the vertical levels of the forest. The canopy structure plays an important role in regulating the availability and intensity of light on the forest floor [36]. By increasing the difference in specific leaf area between individuals, plants can more fully utilize the light environment at different vertical levels.

Light is the key limiting factor affecting tree growth in subtropical and tropical forests, because light penetrates vertically and its intensity declines sharply with increasing canopy depth [19]. Evolution related to the light gradient can explain the successional dynamics of forest ecosystems, suggesting that the coexistence and biodiversity of tree species is partly maintained by niche differentiation [39]. This indicates that plants can increase their niche breadth by increasing the intraspecific variation of functional traits, thereby enhancing their adaptability to the environment [31]. Moreover, significant intraspecific differences are also related to leaf age. Liu et al. [40] emphasized that leaf phenology and plant age played an important role in the variation of intraspecific traits and the relationship between leaf traits. Previous studies demonstrated that there was a significant increase in leaf chlorophyll content in evergreen late-successional conifer forests, due to the age-dependent re-allocation of nitrogen to light-harvesting activities [41,42]. Therefore, we proposed that exploring the pattern of leaf traits along the vertical profile of the canopy can provide a new perspective for understanding the trade-off strategy of individual plants and the mechanism of species coexistence.

\subsection{Correlation of Leaf Traits across the Vertical Canopy Profile}

Our results showed that most leaf traits (except Flav and NBI) were moderately or highly correlated with the others, and SLA had the strongest correlation with the other traits at the upper layer, while $\mathrm{CHL}_{\text {area }}$ had the strongest correlation with the other traits at the lower layer. This result revealed that different strategies should be adopted when selecting varying leaf traits during field sampling. Namely, it could be more efficient to collect leaf samples from the lower layer for $\mathrm{CHL}_{\text {area }}$, and upper layer for SLA. Moreover, the production of Flav is frequently accompanied by a tolerance to enhanced ultraviolet radiation [43]. Flav is a filter of ultraviolet radiation for mesophyll, and it can prevent ultraviolet-induced damage to DNA, photosynthetic apparatus, and membrane lipids [44]. Additionally, Flav plays an important role in regulating free radical scavenging activity [45]. The significant increase in Flav from the lower to the upper layer can be explained by the fact that temperature reduces the content of Flav [46], and previous studies showed that the mean temperature and ultraviolet light increased from the lower shrub to the upper canopy of tall trees in the Dinghushan Nature Reserve [32]. However, Flav was usually neglected in remote sensing studies of leaf traits.

\subsection{The Impact of Vertical Canopy Position on Leaf Spectral Reflectance}

Our results showed that the bivariate relationship linking leaf spectra and leaf traits was canopy-position dependent (Figure 9). To some extent, vertical canopy position could change the y-axis intercept of the relationship linking spectra and leaf traits. In most cases, spectral analysis at the species level reflected major spectral differences within the visible and red edge region (Figure 5), suggesting that leaf spectra were species dependent 
across different vertical canopy positions. Meanwhile, the shade-tolerant species (Crypch, Crypco, and Machch) and light-demanding species showed contrasting spectrum patterns across different vertical canopy positions. The variation of spectra between different species can be largely due to different growth strategies of plants, and the allocation and immobilization of leaf traits can be affected by these strategies. Shade-tolerant species often live in light-limiting conditions with the depletion of blue light, and they employ the strategy of plant trait alteration to maximize light capture. In contrast, shade-intolerant species can hold a wider spectral range of light and have an excellent capacity to cope with excessive irradiance [47].

At the species level, tree tissue (e.g., leaf, flower, and woody branch) biochemistry, canopy structure (e.g., branch density and leaf area index), soil beneath the canopy, and phenology play a major role in dominating vegetation spectral features $[48,49]$. For green and healthy leaves, the absorption features in the visible region $(400-700 \mathrm{~nm})$ are strongly affected by leaf pigments (e.g., chlorophyll and carotenoids) [48]; the absorption features centered at the wavelengths of 970 and $1200 \mathrm{~nm}$ are dominated by leaf water [49]; and in the shortwave infrared region (1500-2450 nm), the absorption features of other chemical components (e.g., lignin, cellulose, and nitrogen) are often masked by the strong absorption of water centered at $1950 \mathrm{~nm}$ [50]. Moreover, the structure of internal and surface tissue, which strongly affects multiplicative scatter and the transmission of photons within the leaves and canopy [51], is also an important factor influencing vegetation spectral features.

Photon absorption and the fluorescence of chloroplast in leaves also affect the spectrum shape in the red edge region $(680-760 \mathrm{~nm})$ [52]. Several studies have demonstrated that a higher content of leaf chlorophyll always leads to a higher red edge area with the red edge position closer to longer wavebands [48]. Significant wavebands for the spectral separability of leaf samples (Figures 6-8) demonstrated that leaf spectra had good capabilities to characterize the variation of leaf traits across different canopy layers. The wavebands between $400-850 \mathrm{~nm}$, especially the two peaks ( $534 \mathrm{~nm}$ in the green region and $720 \mathrm{~nm}$ in the red edge region), were strongly influenced by $\mathrm{CHL}_{\text {area }}$ and $\mathrm{N}$, which agrees with the results of previous studies [48]. However, we found that the spectra of the lower layer were more sensitive compared to the middle and upper layer. Moreover, our results showed that the lower layer of EWT was more sensitive at the wavelengths of 970,1200, 1450, 1950, and $2250 \mathrm{~nm}$. The sensitive wavelengths within the range of the near-infrared and shortwave infrared region have been confirmed by previous studies [53,54], while our results further revealed the lower layer was more appropriate for detecting water content.

We found that the wavelengths of 2138-2160 and 1400-1890 nm were the most important spectral regions for estimating leaf flavonoid for the pooled dataset, while a recent study also found that the flavonoid concentration of Moringa oleifera cultivars was associated with the wavelengths 1344, 1345, 1351, 1428, 1480, 1986, 1998, 2085, 2111, 2135, 2040, and $2164 \mathrm{~nm}$ [55]. The differences between sensitive wavelengths can be attributed to leaf structure, geometry, leaf water content, and other confounding factors [55]. We also revealed that the upper layer of leaves was more sensitive for tracking the variability of flavonoid compared to the middle and lower layer.

\section{Conclusions}

We used a tower crane to explore the effect of different canopy layers on the leaf traits and leaf spectra of six dominant species in the subtropical evergreen broadleaved forest. We can draw the following conclusions:

(1) The vertical canopy position and species significantly affected the variation of leaf traits;

(2) The leaf spectra had contrasting patterns for light-demanding (Castch, Castf, Schisu, and $\mathrm{Machch}$ ) and shade-tolerant species (Crypch and $\mathrm{Crypco}$ ) along the vertical profile at the visible spectral range, but consistent patterns at the shortwave infrared range.

(3) The spectra at the lower and upper canopy layer were more sensitive for tracking the variability of $\mathrm{CHL}_{\text {area }}$ and Flav. 
Our results proved the feasibility of correlating leaf spectra with different leaf traits across different canopy layers and species using a tower crane. This can provide important implications for sampling strategies within the canopy and for scaling up strategies of studying leaf traits at the leaf to canopy and community scale. The previous assumption that leaf traits and the relationship among leaf spectra within the canopy are homogeneous should be taken with caution. Our results showed that the leaf traits of the collected samples and their corresponding reflectance spectra along the vertical profile were varied. Understanding the impact of the vertical heterogeneity of leaf traits within the canopy and the relationship between leaf traits and spectra can help to explore the factors influencing the leaf and canopy reflectance of tall trees.

We suggest that it is important to choose a suitable canopy layer for the field sampling of tall trees. With the tower crane technology, we could choose the top canopy to associate leaf traits with UAV or space-borne remote sensing data; without the tower crane, it is recommended to select the sunlit leaves from the lower canopy layer for a spectral estimation of the $\mathrm{CHL}_{\text {area }}$ and Flav of tall trees. Although expensive, drones have been developed to assist in collecting foliage from the exposed top canopy of tall trees. However, this procedure is expensive and requires skill. Several other studies have reported the use of cross bows for collecting sunlit leaf samples from the top canopy of tall trees [56].

Many studies have paid very little attention to Flav, which is an important trait in regulating plant growth under different intensities of sunlight irradiance. At present, the application of several hyperspectral satellites (e.g., Zhuhai-1 of China and PRISMA of Italy) and UAV hyperspectral sensors in the field of vegetation remote sensing make it feasible to derive spectral indices related to the spatial distribution of leaf Flav. Moreover, future research will focus on using hyperspectral and LiDAR data for exploring three-dimensional variability in leaf traits.

Supplementary Materials: The following are available online at https:/ / www.mdpi.com/article/10 $.3390 /$ rs13245057/s1, Figure S1: Pairwise scatter plots and correlation of the eight leaf traits (EWT, $\mathrm{C}_{\text {area }}, \mathrm{N}_{\text {area }}, \mathrm{P}_{\text {area }}$, SLA, CHLarea, Flav, and NBI) for the six species (Castch, Castfi, Crypch, Crypco, Machch, and Schisu). The upper right panel shows the pairwise pooled data set and correlation coefficients of the three canopy layers. The symbols ${ }^{* * *},{ }^{* *}$, and ${ }^{*}$ represent significance at the 0.001 , 0.01 , and 0.05 levels, respectively.

Author Contributions: Conceptualization, F.Y., T.W. and J.W.; methodology, T.W.G., T.W., J.L. and W.Y.; formal analysis, J.W., F.Y., J.S., Z.W. and T.W.G.; writing-original draft preparation, F.Y.; writing-review and editing, F.Y., T.W.G., J.W. and T.W.; visualization, J.S.; supervision, T.W., J.L. and W.Y.; funding acquisition, Z.W. and W.Y. All authors have read and agreed to the published version of the manuscript.

Funding: This work was funded by the National Natural Science Foundation of China (No. 41901060 and 41671430).

Institutional Review Board Statement: Not applicable.

Informed Consent Statement: Not applicable.

Data Availability Statement: Not applicable.

Acknowledgments: We thank the anonymous reviewers for their constructive comments and suggestions, which improved the manuscript.

Conflicts of Interest: The authors declare no conflict of interest.

\section{References}

1. Fassnacht, F.E.; Latifi, H.; Stereńczak, K.; Modzelewska, A.; Lefsky, M.; Waser, L.T.; Straub, C.; Ghosh, A. Review of studies on tree species classification from remotely sensed data. Remote Sens. Environ. 2016, 186, 64-87. [CrossRef]

2. Zhou, G.; Houlton, B.Z.; Wang, W.; Huang, W.; Xiao, Y.; Zhang, Q.; Liu, S.; Cao, M.; Wang, X.; Wang, S.; et al. Substantial reorganization of China's tropical and subtropical forests: Based on the permanent plots. Global Chang. Biol. 2014, 20, 240-250. [CrossRef] [PubMed] 
3. Dassot, M.; Constant, T.; Fournier, M. The use of terrestrial LiDAR technology in forest science: Application fields, benefits and challenges. Ann. Forest Sci. 2011, 68, 959-974. [CrossRef]

4. Moreno-Martínez, Á.; Camps-Valls, G.; Kattge, J.; Robinson, N.; Reichstein, M.; van Bodegom, P.; Kramer, K.; Cornelissen, J.H.C.; Reich, P.; Bahn, M.; et al. A methodology to derive global maps of leaf traits using remote sensing and climate data. Remote Sens. Environ. 2018, 218, 69-88. [CrossRef]

5. Kissling, W.D.; Ahumada, J.A.; Bowser, A.; Fernandez, M.; Fernandez, N.; Garcia, E.A.; Guralnick, R.P.; Isaac, N.J.B.; Kelling, S.; Los, W.; et al. Building essential biodiversity variables (EBVs) of species distribution and abundance at a global scale. Biol. Rev. 2018, 93, 600-625. [CrossRef]

6. Asner, G.P.; Martin, R.E.; Anderson, C.B.; Knapp, D.E. Quantifying forest canopy traits: Imaging spectroscopy versus field survey. Remote Sens. Environ. 2015, 158, 15-27. [CrossRef]

7. Cho, M.A.; Mathieu, R.; Asner, G.P.; Naidoo, L.; van Aardt, J.; Ramoelo, A.; Debba, P.; Wessels, K.; Main, R.; Smit, I.P.J.; et al. Mapping tree species composition in South African savannas using an integrated airborne spectral and LiDAR system. Remote Sens. Environ. 2012, 125, 214-226. [CrossRef]

8. Lefcheck, J.S.; Bastazini, V.A.G.; Griffin, J.N. Choosing and using multiple traits in functional diversity research. Environ. Conserv. 2014, 42, 104-107. [CrossRef]

9. Kraft, N.J.; Cornwell, W.K.; Webb, C.O.; Ackerly, D.D. Trait Evolution, Community Assembly, and the Phylogenetic Structure of Ecological Communities. Am. Nat. 2007, 170, 271-283. [CrossRef] [PubMed]

10. Violle, C.; Navas, M.L.; Vile, D.; Kazakou, E.; Fortunel, C.; Hummel, I.; Garnier, E. Let the concept of trait be functional! Oikos 2007, 116, 882-892. [CrossRef]

11. He, N.; Liu, C.; Tian, M.; Li, M.; Yang, H.; Yu, G.; Guo, D.; Smith, M.D.; Yu, Q.; Hou, J.; et al. Variation in leaf anatomical traits from tropical to cold-temperate forests and linkage to ecosystem functions. Funct. Ecol. 2017, 32, 10-19. [CrossRef]

12. Albert, C.H.; Thuiller, W.; Yoccoz, N.G.; Douzet, R.; Aubert, S.; Lavorel, S. A multi-trait approach reveals the structure and the relative importance of intra- vs. interspecific variability in plant traits. Funct. Ecol. 2010, 24, 1192-1201. [CrossRef]

13. Wright, I.J.; Reich, P.B.; Westoby, M.; Ackerly, D.D.; Baruch, Z.; Bongers, F.; Cavender-Bares, J.; Chapin, T.; Cornelissen, J.H.; Diemer, M.; et al. The worldwide leaf economics spectrum. Nature 2004, 428, 821-827. [CrossRef]

14. He, N.; Liu, C.; Piao, S.; Sack, L.; Xu, L.; Luo, Y.; He, J.; Han, X.; Zhou, G.; Zhou, X.; et al. Ecosystem Traits Linking Functional Traits to Macroecology. Trends Ecol. Evol. 2019, 34, 200-210. [CrossRef]

15. Gara, T.; Darvishzadeh, R.; Skidmore, A.; Wang, T. Impact of Vertical Canopy Position on Leaf Spectral Properties and Traits across Multiple Species. Remote Sens. 2018, 10, 346. [CrossRef]

16. Thomas, V.; Treitz, P.; McCaughey, J.H.; Noland, T.; Rich, L. Canopy chlorophyll concentration estimation using hyperspectral and lidar data for a boreal mixedwood forest in northern Ontario, Canada. Int. J. Remote Sens. 2008, 29, 1029-1052. [CrossRef]

17. Wang, Q.; Li, P. Canopy vertical heterogeneity plays a critical role in reflectance simulation. Agr. Forest Meteorol. 2013, 169, 111-121. [CrossRef]

18. Petter, G.; Wagner, K.; Wanek, W.; Sánchez Delgado, E.J.; Zotz, G.; Cabral, J.S.; Kreft, H.; Baltzer, J. Functional leaf traits of vascular epiphytes: Vertical trends within the forest, intra- and interspecific trait variability, and taxonomic signals. Funct. Ecol. 2015, 30, 188-198. [CrossRef]

19. Weerasinghe, L.K.; Creek, D.; Crous, K.Y.; Xiang, S.; Liddell, M.J.; Turnbull, M.H.; Atkin, O.K. Canopy position affects the relationships between leaf respiration and associated traits in a tropical rainforest in Far North Queensland. Tree Physiol. 2014, 34, 564-584. [CrossRef]

20. Widlowski, J.-L.; Taberner, M.; Pinty, B.; Bruniquel-Pinel, V.; Disney, M.; Fernandes, R.; Gastellu-Etchegorry, J.-P.; Gobron, N.; Kuusk, A.; Lavergne, T.; et al. Third Radiation Transfer Model Intercomparison (RAMI) exercise: Documenting progress in canopy reflectance models. J. Geophys. Res. Atmos. 2007, 112, D09111. [CrossRef]

21. Koike, T.; Kitao, M.; Maruyama, Y.; Mori, S.; Lei, T.T. Leaf morphology and photosynthetic adjustments among deciduous broad-leaved trees within the vertical canopy profile. Tree Physiol. 2001, 21, 951-958. [CrossRef]

22. Van Wittenberghe, S.; Alonso, L.; Verrelst, J.; Hermans, I.; Valcke, R.; Veroustraete, F.; Moreno, J.; Samson, R. A field study on solar-induced chlorophyll fluorescence and pigment parameters along a vertical canopy gradient of four tree species in an urban environment. Sci. Total Environ. 2014, 466, 185-194. [CrossRef] [PubMed]

23. Li, H.; Zhao, C.; Huang, W.; Yang, G. Non-uniform vertical nitrogen distribution within plant canopy and its estimation by remote sensing: A review. Field Crop. Res. 2013, 142, 75-84. [CrossRef]

24. Kitajima, K.; Mulkey, S.S.; Wright, S.J. Variation in crown light utilization characteristics among tropical canopy trees. Ann. Bot. 2005, 95, 535-547. [CrossRef] [PubMed]

25. Wang, Z.; Skidmore, A.K.; Darvishzadeh, R.; Heiden, U.; Heurich, M.; Wang, T. Leaf Nitrogen Content Indirectly Estimated by Leaf Traits Derived From the PROSPECT Model. IEEE J.-Stars 2015, 8, 3172-3182. [CrossRef]

26. Lowman, M.D.; Schowalter, T.D. Plant science in forest canopies-The first 30 years of advances and challenges (1980-2010). New Phytol. 2012, 194, 12-27. [CrossRef]

27. Schmit-Neuerburg, V. Dynamics of Vascular Epiphyte Vegetation in the Venezuelan Lowland Rain Forest of the Surumoni Crane Project. Ph.D. Thesis, Rheinische Friedrich-Wilhelms-Universität, Bonn, Germany, 2002.

28. Parker, G.G.; Smith, A.P.; Hogan, K.P. Access to the Upper Forest Canopy with a Large Tower Crane. Bioscience 1992, 42, 664-670. [CrossRef] 
29. Pennisi, E. Forest research-Sky-high experiments. Science 2005, 309, 1314-1315. [CrossRef]

30. Ni, Y.; Wang, T.; Cao, H.; Li, Y.; Bin, Y.; Zhang, R.; Wang, Y.; Lian, J.; Ye, W. An old-growth subtropical evergreen broadleaved forest suffered more damage from Typhoon Mangkhut than an adjacent secondary forest. For. Ecol. Manag. 2021, $496,119433$. [CrossRef]

31. Condit, R. Tropical Forest Census Plots-Methods and Results From Barro Colorado Island, Panama and a Comparison With Other Plots; Springer: Georgetown, TX, USA, 1998.

32. Gui, X.; Lian, J.; Zhang, R.; Li, Y.; Shen, H.; Ni, Y.; Ye, W. Vertical structure and its biodiversity in a subtropical evergreen broadleaved forest at Dinghushan in Guangdong Province, China. Biodivers. Sci. 2019, 27, 619-629. [CrossRef]

33. Cornelissen, J.H.C.; Lavorel, S.; Garnier, E.; Diaz, S.; Buchmann, N.; Gurvich, D.E.; Reich, P.B.; ter Steege, H.; Morgan, H.D.; van der Heijden, M.G.A.; et al. A handbook of protocols for standardised and easy measurement of plant functional traits worldwide. Aust. J. Bot. 2003, 51, 335-380. [CrossRef]

34. Markwell, J.; Osterman, J.C.; Mitchell, J.L. Calibration of the Minolta SPAD-502 leaf chlorophyll meter. Photosynth. Res. 1995, 46, 467-472. [CrossRef]

35. Fajardo, A.; Siefert, A. Phenological variation of leaf functional traits within species. Oecologia 2016, 180, 951-959. [CrossRef]

36. Klopčič, M.; Simončič, T.; Bončina, A. Comparison of regeneration and recruitment of shade-tolerant and light-demanding tree species in mixed uneven-aged forests: Experiences from the Dinaric region. Forestry 2015, 88, 552-563. [CrossRef]

37. Kull, O.; Niinemets, Ü. Distribution of leaf photosynthetic properties in tree canopies: Comparison of species with different shade tolerance. Funct. Ecol. 1998, 12, 472-479. [CrossRef]

38. Kenzo, T.; Inoue, Y.; Yoshimura, M.; Yamashita, M.; Tanaka-Oda, A.; Ichie, T. Height-related changes in leaf photosynthetic traits in diverse Bornean tropical rain forest trees. Oecologia 2015, 177, 191-202. [CrossRef]

39. Kobe, R.K. Light gradient partitioning among tropical tree species through differential seedling mortality and growth. Ecology 1999, 80, 187-201. [CrossRef]

40. Liu, Z.; Jiang, F.; Li, F.; Jin, G. Coordination of intra and inter-species leaf traits according to leaf phenology and plant age for three temperate broadleaf species with different shade tolerances. For. Ecol. Manag. 2019, 434, 63-75. [CrossRef]

41. Niinemets, U. Photosynthesis and resource distribution through plant canopies. Plant Cell Environ. 2007, 30, 1052-1071. [CrossRef] [PubMed]

42. Scheepens, J.F.; Frei, E.S.; Stocklin, J. Genotypic and environmental variation in specific leaf area in a widespread Alpine plant after transplantation to different altitudes. Oecologia 2010, 164, 141-150. [CrossRef]

43. Láposi, R.; Veres, S.; Lakatos, G.; Oláh, V.; Fieldsend, A.; Mészáros, I. Responses of leaf traits of European beech (Fagus sylvatica L.) saplings to supplemental UV-B radiation and UV-B exclusion. Agric. Forest Meteorol. 2009, 149, 745-755. [CrossRef]

44. Kootstra, A. Protection from UV-B-induced DNA damage by flavonoids. Plant Mol. Biol. 1994, 26, 771-774. [CrossRef]

45. Yamasaki, H.; Sakihama, Y.; Ikehara, N. Flavonoid-Peroxidase Reaction as a Detoxification Mechanism of Plant Cells against $\mathrm{H}_{2} \mathrm{O}_{2}$. Plant Physiol. 1997, 115, 1405-1412. [CrossRef]

46. Randriamanana, T.R.; Lavola, A.; Julkunen-Tiitto, R. Interactive effects of supplemental UV-B and temperature in European aspen seedlings: Implications for growth, leaf traits, phenolic defense and associated organisms. Plant Physiol. Biochem. 2015, 93, 84-93. [CrossRef] [PubMed]

47. Wang, Q.W.; Robson, T.M.; Pieristè, M.; Oguro, M.; Oguchi, R.; Murai, Y.; Kurokawa, H.; Cao, K.F. Testing trait plasticity over the range of spectral composition of sunlight in forb species differing in shade tolerance. J. Ecol. 2020, 108, 1923-1940. [CrossRef]

48. Clark, M.L.; Roberts, D.A. Species-Level Differences in Hyperspectral Metrics among Tropical Rainforest Trees as Determined by a Tree-Based Classifier. Remote Sens. 2012, 4, 1820-1855. [CrossRef]

49. Asner, G.P. Biophysical and Biochemical Sources of Variability in Canopy Reflectance. Remote Sens. Environ. 1998, 64, $234-253$. [CrossRef]

50. Kokaly, R.F.; Asner, G.P.; Ollinger, S.V.; Martin, M.E.; Wessman, C.A. Characterizing canopy biochemistry from imaging spectroscopy and its application to ecosystem studies. Remote Sens. Environ. 2009, 113, S78-S91. [CrossRef]

51. Asner, G.P.; Martin, R.E. Spectral and chemical analysis of tropical forests: Scaling from leaf to canopy levels. Remote Sens. Environ. 2008, 112, 3958-3970. [CrossRef]

52. Ustin, S.L.; Gitelson, A.A.; Jacquemoud, S.; Schaepman, M.; Asner, G.P.; Gamon, J.A.; Zarco-Tejada, P. Retrieval of foliar information about plant pigment systems from high resolution spectroscopy. Remote Sens. Environ. 2009, 113, S67-S77. [CrossRef]

53. Ceccato, P.; Flasse, S.; Tarantola, S.; Jacquemoud, S.; Gregoire, J.M. Detecting vegetation leaf water content using reflectance in the optical domain. Remote Sens. Environ. 2001, 77, 22-33. [CrossRef]

54. Hunt, E.R.; Rock, B.N. Detection of changes in leaf water content using Near- and Middle-Infrared reflectances. Remote Sens. Environ. 1989, 30, 43-54. [CrossRef]

55. Tshabalala, T.; Abdel-Rahman, E.M.; Masemola, C.; Ncube, B.; Ndhlala, A.R.; Mutanga, O. Predicting medicinal phytochemicals of Moringa oleifera using hyperspectral reflectance of tree canopies. Int. J. Remote Sens. 2021, 42, 3955-3980. [CrossRef]

56. Gara, T.W.; Darvishzadeh, R.; Skidmore, A.K.; Wang, T.; Heurich, M. Evaluating the performance of PROSPECT in the retrieval of leaf traits across canopy throughout the growing season. Int. J. Appl. Earth Obs. Geoinf. 2019, 83, 101919. [CrossRef] 